\title{
Respecting Parents in the Ethical Ideas of Al-Ghazali
}

\author{
Fayzullaeva* \\ Candidate of Historical Sciences, Khujand State University, Tajikistan
}

Submission: November 26, 2018; Published: December 06, 2018

*Corresponding author: Fayzullaeva, Candidate of Historical Sciences, Khujand State University, Tajikistan

Abstract

The article outlines Abuhamid al-Ghazali's ethical ideas regarding parents. The article motivates for respect, care, love and protects parents as moral norms.

Keywords: Family; Parents; Children; Morality; Obligation; Respect

\section{Mini Review}

Abuhamid Muhammad al-Ghazali (1059-1111) is one of the famous philosopher scholars who have contributed to the development of science. He has also studied research in the field of ethics, including the family ethics survey. Al-Ghazali teaches parental respect and teaches children to be grateful for the goodness of their parents, rejoice in their hearts with gifts; if parents make a mistake to work, it explains how poorly it is; and they will be able to restrain their hands, and even endure their oppression $[1,2]$.

The scientist advises not to leave old parents and protect them from the oppressive environment; child up to the maximum possible for the parent; because they have worked for many years for the child to grow; after the death of the parents, they always remember them, and the parents of the sisters and brothers need to have a good relationship. Children need to be confident and confident about their parents, especially older parents, whose physical strength and health are concerned that they are caring about the kindness of the children and grandchildren [3]. It does not matter if you do not like it, and you are not going to be able to do that. Children should enjoy the experience of the life of the older parent. Because humanity has learned the lessons of life from theirs parents, and they will be succeeded without repeating their mistakes.

Therefore, it should be taught to respect the elderly from childhood [4]. Young people should be tolerant of their parents when they are cautious and quick-witted in order not to upset them, even in a tense state, to be restrained, not to say bad things if they are capricious as a sign of old age and do not pay much attention for it. It is also important to honor the parents of the spouse (or spouses), since these behaviors increase the love for the husband or wife.
According to Al-Ghazali, the happiness of the children depends on the parents prayers in all world, as their prayers will be accepted, their spells are like shooting, which will not go back and would fall right on target and destroy; one who has a conscience will not upset the parents; there is a sin that is as huge like as mountains of the earth, if a child does not respond to the call of the parents, then he will take this sin on his soul. A scientist considers virtue to parents more respectful than prayers. He says that the one who respects the parents will live a successful life, but the life of the offender will be short and the one who respects the parents God will reward him by being in a row of honour [5]. Conversely, the one who offended the parents will be in a row of sinners. AlGhazali indicates the high status of parents and demands that they should be given high respect. From the point of view of the science of ethics and humanity, parents are respectable [6]. In fact, the role of the mother and father who raised the child with love in the child's life is very high. To love parents, to honor their age and work is the duty of every child. Lord said: "Be grateful to Me and to your parents." (Quran 31:14).

Even though the ethical views of the scientist are written in the Middle Ages, but they have educational value and at the present time. The moral teachings of Muhammad al-Ghazali is an ethical prescription and contributes to the expansion of people's ethical horizons.

\section{References}

1. Koran (2007) Translation by M. Umarov. - Dushanbe, Tajikistan pp. 423.

2. Abuhamid al-Ghazali (2011) Nasihat-ul-muluk. Irfon, Dushanbe, Tajikistan

3. Abuhamid al-Ghazali (2006) Research innermost secrets of the heart. Ansar, Moscow, Russia. 
4. Abuhamid al-Ghazali (2005) Kimëi saodat. Adolat, Tashkent Uzbekistan.

5. Abuhamid al-Ghazali (2002) Mukoshafat-ul-Qulub. Adolat, Tashkent, Uzbekistan.
6. Fayzulloeva MSh (2018) Ethical ideas in the philosophy of Abuhamid Muhammad al-Ghazali. Scholars' Press, Moldova, Europe.

\section{Your next submission with Juniper Publishers will reach you the below assets}

- Quality Editorial service

- Swift Peer Review

- Reprints availability

- E-prints Service

- Manuscript Podcast for convenient understanding

- Global attainment for your research

- Manuscript accessibility in different formats

( Pdf, E-pub, Full Text, Audio)

- Unceasing customer service

Track the below URL for one-step submission https://juniperpublishers.com/online-submission.php 